\title{
Exotic plus native: findings in an unscheduled fish duoculture
}

\author{
David Julián Palma-Cancino ${ }^{1}$ (D), Mao Ernesto Rafael Basto-Rosales ${ }^{2}$ \\ Carlos Alfonso Álvarez-González ${ }^{3}(\mathbb{D})$, Rafael Martínez-García ${ }^{3}\left(\mathbb{D}\right.$, Daniel Badillo-Zapata ${ }^{1,4}$ \\ Olimpia Chong-Carrillo ${ }^{1} \mathbb{D}$ \& Fernando Vega-Villasante ${ }^{1} \mathbb{C}$ \\ ${ }^{1}$ Laboratorio de Calidad de Agua y Acuicultura Experimental, Departamento de Ciencias Biológicas \\ Centro Universitario de la Costa, Universidad de Guadalajara \\ Puerto Vallarta, Jalisco, México \\ ${ }^{2}$ Tecnológico Nacional de Bahía de Banderas, La Cruz de Huanacaxtle \\ Bahía de Banderas, Nayarit, México \\ ${ }^{3}$ Laboratorio de Acuicultura Tropical, División Académica de Ciencias Biológicas \\ Universidad Juárez Autónoma de Tabasco, Villahermosa, Tabasco, México \\ ${ }^{4}$ Programa Cátedra CONACYT, Consejo Nacional de Ciencia y Tecnología \\ Ciudad de México, México \\ Corresponding author: Fernando Vega-Villasante (fernandovega.villasante @ gmail.com)
}

\begin{abstract}
The development of native fish aquaculture represents an important alternative to mitigate ecological displacement generated by exotic fish. The introduction of native fish in polyculture systems with high commercial value fishes has provided a useful strategy for sustainable aquaculture development. The present study aims to provide information on tilapia, as an exotic species, and Dormitator latifrons, as a native species, in a duo culture not programmed as such. Using juveniles of Pacific fat sleeper D. latifrons leftovers from another experiment, we decide to analyze and report the biological feasibility of a duoculture system with this species and Nile tilapia (Oreochromis niloticus). Two hundred fifty organisms of each species were placed for 90 days in a concrete tank with a capacity of $50 \mathrm{~m}^{3}$ to evaluate the compatibility of these species. The biological variables measured were growth, survival, feed conversion rate, and protein efficiency. The findings suggest a good interaction between species, with adequate growths and a survival rate of $98 \%$. No antagonistic behavior was observed during confinement, suggesting the duoculture of these species may represent a good alternative for tropical sustainable aquaculture.
\end{abstract}

Keywords: Dormitator latifrons; Oreochromis niloticus; Nile tilapia; native fish; polyculture; sustainable aquaculture

The sustainable future of aquaculture will depend (between other factors) on our will and capacity to diversify the number of farmed species and thereby avoid, as much as possible, the introduction of the same species throughout the world (Boyd et al. 2020). The development of native fish aquaculture represents an important alternative to mitigate ecological displacement generated by exotic fish with more developed markets, like tilapias Oreochromis spp. and carps Cyprinus spp. (Basto-Rosales et al. 2019). Dormitator latifrons, commonly known as Pacific fat sleeper, chame, puyeque, or popoyote, represent a potentially important native fish resource in Mexico's Pacific coast (BastoRosales et al. 2019). Culture technology of this fish is partially dominated in Ecuador (Castro-Rivera et al. 2005, Rodríguez-Montes de Oca et al. 2012). In recent years in Mexico, studies of this fish were mainly focused on the nutrition (Badillo-Zapata et al. 2018, López-Huerta et al. 2018), parasitology (ViolanteGonzález et al. 2008, Vega-Villasante et al. 2017), meat quality protein (Basto-Rosales et al. 2020), and low density monoculture (Basto-Rosales et al. 2019).

Corresponding editor: Patricio Dantagnan 
The introduction of a low commercial value fish in polyculture or duoculture systems, including a highvalue species with similar biology and aquaculture technology, has been suggested to consolidate sustainable aquaculture for native fishes (Munguti et al. 2014). Tilapia (Oreochromis spp., Tilapia spp. \& Sarotherodon spp.) represents the second largest fishes cultivated worldwide (FAO 2018). The Nile tilapia Oreochromis niloticus is extensively used in polyculture systems worldwide (Wang \& Lu 2016).

The present study aims to provide information on the behavior, both in development and attitude, of tilapia, an exotic species, and D. latifrons, a native species, in a duoculture that was not programmed as such. In two simultaneous but different studies (related to school practices and doctoral research), juveniles of both species that were not used were placed in the same concrete pond, with the simple idea of conserving the organisms for possible future research. For the above reason, the necessary replicas were not established to be considered a formal study. Even so, given that the fish had been previously weighed (due to the original studies), it was considered, days later, that it would be worthwhile to carry out observations on their development and behavior, since there were no records, in our country, of such a type of duoculture. After 90 days of culture, the findings were interesting enough to consider their dissemination, with the intention that they would serve as an incentive for future betterprogrammed studies with well-established protocols.

The juveniles of $D$. latifrons (remaining from the other studies) were originally captured in Quelele Lagoon localized in Bahía de Banderas, Nayarit, Mexico, at $20^{\circ} 43^{\prime} 25.43 " \mathrm{~N}, 105^{\circ} 18^{\prime} 03.63 " \mathrm{~W}$. O. niloticus (Stirling) juveniles were previously obtained from an aquaculture farm in Manzanillo, Colima, Mexico. Fishes were placed in a fish-free concrete pond with a capacity of $50 \mathrm{~m}^{3}$, previously filled (three weeks early) with running potable water provided by the municipal network from Cruz de Huanacaxtle, Nayarit, Mexico with a turbidity of $15 \mathrm{~cm}$ (green water). Juvenile initial weight was $16.91 \pm 5.60 \mathrm{~g}$ for $D$. latifrons and $13.12 \pm$ $4.33 \mathrm{~g}$ for $O$. niloticus. The system included constant aeration provided by a $1 \mathrm{hp}$ blower $\left(\right.$ Pioneer $^{\circledR}$ ) and a weekly $5 \%$ water replacement.

Since no previous adjustment of fish number was made (although the total number introduced into the pond was known), once it was considered to carry out the observations of the duoculture, several organisms were removed to adjust to a total of 10 ind $\mathrm{m}^{-3}$ for both species (a total of 250 individuals per species), to have a proportion of $50-50 \%$ of each species. The feeding schedule was two times a day (08:00 and 19:00 h) using commercial feed Nutripec ${ }^{\mathrm{TM}}$ (Purina $^{\circledR}, 35 \%$ protein, $8 \%$ lipids). A daily fed portion was adjusted according to total biomass at $8 \%$ during the first half of culture (until day 45) and 3\% (after day 45). Observations on the feeding behavior of both species were made during feeding times. Additional observations were carried out throughout the day, between feeding periods, and until one hour after the last feed of the day (20:00 h). Biometrics were taken monthly from random samples of 30 individuals per species, measuring total weight in grams using a digital scale (Rhino ${ }^{\circledR}$ ) and total length in centimeters from head to caudal fin using an ichthyometer.

Physical an chemical parameters were measured daily just before feeding time (08:00 and 19:00 h); water temperature and dissolved oxygen were registered using a multiparameter Pro Plus device $\left(\mathrm{YSI}^{\circledR}\right)$, and water turbidity was estimate weekly using a Secchi disc.

The following equations were used: gained weight, $\mathrm{GW}=\mathrm{Wf}-\mathrm{Wi}$, where $\mathrm{Wf}$ is final weight, and $\mathrm{Wi}$ is initial weight, to evaluate the fish's growth. Specific growth rate, $\mathrm{SGR}=[(\ln \mathrm{Wf}-\ln \mathrm{Wi}) / \mathrm{t}] \times 100$, where $\mathrm{ln}$ is the natural logarithm and $\mathrm{t}$ is time in days. Protein efficiency rate, $\mathrm{PER}=\mathrm{GW}$ / weight of delivered protein (amount of feed delivered per percentage of feed protein / 100). Feed conversion rate, FCR $=$ feed consumed $/ \mathrm{GW}$. Survival rate, $\% \mathrm{SR}=$ (final number of individuals $\times 100$ ) / number of initial individuals).

Various statistical analyzes were performed on the zootechnical data obtained during measures. The final weight (Wf) of both treatments (D. latifrons and $O$. niloticus) were evaluated with Kolmogorov-Smirnov (K-S) normality test and the Levene homoscedasticity test. A Mann-Whitney U test with a $95 \%$ confidence level was performed to determine statistical differences between growths. For GW, \% GW and SGR, K-S and $t$ student tests were performed to determinate statistical differences. All statistical analyzes were performed using Minitab ${ }^{\circledR} 18$ software (Minitab Inc.).

After 90 days of culture, Wf $(187.50 \pm 70.30 \mathrm{~g})$, GW $(174.40 \pm 37.30 \mathrm{~g}), \% \mathrm{GW}(1,431.30 \pm 46.72 \%)$ and SGR (2.96 \pm 0.08$)$ of $O$. niloticus presented superior values than $D$. latifrons (Table 1). Statistical differences were obtained $(P<0.05)$ between species growth and SGR. The PER was 2.33, and the FCR was 1.22:1 for both species. Feed total consumption during 90 days was 95,040.65 $\mathrm{g}$ between the two species, and the final total biomass gained was $77,400.60 \mathrm{~g}$. The survival rate for both species was $98 \%$ during the cultivation process (Table 1). The water quality parameters fluctuated between the acceptable range for tropical freshwater fishes used in aquaculture (Table 2). 
Table 1. Zootechnical parameters from the duoculture of Dormitator latifrons and Oreochromis niloticus in concrete ponds. Mean \pm standard deviation. Different letters in each row represent statistical differences $(P<0.05)$.

\begin{tabular}{lcc}
\hline Zootechnical parameters & D. latifrons & O. niloticus \\
\hline Initial weight $(\mathrm{g})$ & $16.91 \pm 5.60^{\mathrm{a}}$ & $13.12 \pm 4.33^{\mathrm{b}}$ \\
Final weight $(\mathrm{g})$ & $152.14 \pm 62.64^{\mathrm{b}}$ & $187.50 \pm 70.30^{\mathrm{a}}$ \\
Gained weight $(\mathrm{g})$ & $135.21 \pm 34^{\mathrm{b}}$ & $174.40 \pm 37.30^{\mathrm{a}}$ \\
\% Gained weight & $900 \pm 40.30^{\mathrm{b}}$ & $1,431.30 \pm 46.72^{\mathrm{a}}$ \\
Initial biomass $(\mathrm{g})$ & $4,233.32 \pm 5.04$ & $3,270.51 \pm 4.34$ \\
Final biomass $(\mathrm{g})$ & $38,035.80 \pm 62.60$ & $46,868.81 \pm 70.33$ \\
Gained biomass $(\mathrm{g})$ & $33,802.30 \pm 57$ & $43,598.31 \pm 66$ \\
Specific growth rate & $2.44 \pm 0.12^{\mathrm{a}}$ & $2.96 \pm 0.08^{\mathrm{b}}$ \\
Survival (\%) & 98 & 98 \\
\hline Feed conversion ratio & \multicolumn{3}{c}{1.22} \\
Protein efficiency rate & \multicolumn{2}{c}{2.33} \\
Total gained biomass $(\mathrm{g})$ & \multicolumn{2}{c}{$97,400.60$} \\
Total feed consumption $(\mathrm{g})$ & \multicolumn{3}{c}{$95,040.65$} \\
\hline
\end{tabular}

Table 2. Mean daily water quality parameters observed during the polyculture (Dormitator latifrons and Oreochromis niloticus) using concrete ponds. Mean \pm standard deviation.

\begin{tabular}{lcccc}
\hline Month & $\begin{array}{c}\text { Temperature } \\
\left({ }^{\circ} \mathrm{C}\right)\end{array}$ & $\begin{array}{c}\text { Dissolved oxygen } \\
\left(\mathrm{mg} \mathrm{L}^{-1}\right)\end{array}$ & $\mathrm{pH}$ & $\begin{array}{c}\text { Turbidity } \\
(\mathrm{cm})\end{array}$ \\
\hline September & $33.3 \pm 0.3$ & $6.5 \pm 0.4$ & $7.1 \pm 0.2$ & $40 \pm 3.0$ \\
October & $30.9 \pm 1.4$ & $6.4 \pm 0.1$ & $7.8 \pm 0.3$ & $40 \pm 1.4$ \\
November & $28.8 \pm 4.5$ & $5.8 \pm 0.3$ & $7.8 \pm 0.2$ & $42 \pm 3.3$ \\
December & $29.8 \pm 0.4$ & $6.0 \pm 0.6$ & $7.8 \pm 0.2$ & $43 \pm 2.4$ \\
\hline
\end{tabular}

These results demonstrate interesting findings. The survival of both species was surprisingly high (98\%); in monocultures, Dormitator showed a survival rate similar to the reported by Basto-Rosales et al. (2019), of $99-100 \%$ in monoculture with different conditions and lower densities; and the survival rate of tilapia was higher to the $96 \%$ reported in Nile tilapia aquaponics (Rahmatullah et al. 2010) or the 78-92\% reported at high stocking densities (superior to 200 ind $\mathrm{m}^{-3}$ ) in semi-extensive monoculture (Ronald et al. 2014). Our findings suggest that $D$. latifrons can endure even higher stocking densities during mono and polyculture production systems with excellent survival.

The high \%SR obtained in our culture shows that the coexistence between both species is peaceful and seems to be a synergistic phenomenon that should be studied. In this sense, it is worth mentioning that these species generally occupy different niches within the pond. Tilapia stay longer in the water column while Dormitator stays at the bottom. In the observations carried out during feeding times, it is only possible to appreciate the presence of tilapia, and it is rare to see Dormitator feeding at the same time. However, in the additional observations (outside the feeding times) and particularly in the afternoon/night hours, more specimens of Dormitator wandering on the pond's surface were observed. This behavior allows the two species to coexist without causing antagonisms by space; however, it is clear that the greater amount of food is used by tilapia and may explain the greater increase in their final weight.

The feeding behavior observations showed there is a low uptake of formulated feed by Dormitator; the latter would force them to seek additional sources of nutrients, which would not be a major problem since being omnivorous/detritivore (Yáñez-Arancibia \& Díaz-González 1977). They can use the same waste from the tilapia and the natural sediments of the pond, which could explain the high survival rates by having greater control of organic matter, taking advantage of one species' residues to benefit the other, and the quality of the water. According to Milstein (1992) and Wang \& Lu (2016), synergistic interactions among fish species may be explained based on several interrelated processes: increase of food resources, improvement of environmental conditions, the proper combination of ecologically different species at adequate densities. We consider that the above was fulfilled in our study, although circumstantial since the duoculture was established a priori and not based on previous studies (non-existent, in fact) that could guide us. Usually, the selection of $O$. niloticus to evaluate a duoculture system 
with other species is based mainly on the easy growth under captive conditions and high commercial impact (Rodríguez-Montes de Oca \& Dabrowski 2015).

D. latifrons survival was relatively similar to that reported by Basto-Rosales et al. (2019); however, mean growth was inferior to that reported by the same authors, who obtained GW over $230 \mathrm{~g}$ monoculture of low stocking densities. Feeding competitors can explain inferior GW in our work (Papoutsoglou et al. $2001)$ and the higher stocking density $\left(10\right.$ ind $\left.\mathrm{m}^{-3}\right)$.

Despite the differences in individual growth in our results, the duoculture of this species appears to be biologically feasible because these fishes do not occupy the same trophic niche, and we do not observe interspecies aggression. The latter coincided with Tahoun et al. (2013), where utilization of $O$. niloticus in polyculture with native fishes presented great survival, FCR, and growth, especially for tilapia.

As a native fish with an underdeveloped regional market, the introduction of $D$. latifrons in a rural semiextensive duoculture with a bigger market size species like $O$. niloticus may positively impact the divulgation of its culture technology, just like some cases with native tropical fishes in Asia (Wang \& Lu 2016). This study represents the first report of the duoculture of $D$. latifrons and $O$. niloticus, and the findings suggest that it may be a feasible production system. Pilot cultures carried out with well-established protocols are necessary to develop the appropriate technology, and this is the goal of our current research.

\section{ACKNOWLEDGMENTS}

This research was partially funded by the Mexico National Council of Science and Technology (CONACYT), grant No. 769329. We wish to thanks the Centro Universitario de la Costa (Universidad de Guadalajara) for the experimental unit and equipment provided to facilitate our research. We appreciate the kind and wise editorial management of the Associate Editor.

\section{REFERENCES}

Badillo-Zapata, D., De Jesús-Zaragoza, J.F., VegaVillasante, F., López-Huerta, J.M., Herrera-Reséndiz, S., Cueto-Cortés, L. \& Guerrero-Galván, S.R. 2018. Requerimiento de proteína y lípidos para el crecimiento de juveniles del pez nativo Dormitator latifrons (Richardson, 1844). Ecosistemas y Recursos Agropecuarios, 5: 345-351.

Basto-Rosales, M.E.R., Rodríguez-Montes de Oca, G.A., Carrillo-Farnés, O., Álvarez-González, C.A., BadilloZapata, D. \& Vega-Villasante, F. 2019. Growth of
Dormitator latifrons under different densities in concrete tanks. Tropical and Subtropical Agroecosystems, 22: 489-493.

Basto-Rosales, M.E.R., Carrillo-Farnés, O., MontoyaMartínez, C.E., Badillo-Zapata, D., Rodríguez-Montes de Oca, G.A., Álvarez-González, C.A., et al. 2020. Meat protein quality of Dormitator latifrons (Pisces: Eleotridae): arguments for use by rural communities. Ecosistemas y Recursos Agropecuarios, 7: e2172.

Boyd, C.E., D'Abramo, L.R., Glencross, B.D., Huyben, D.C., Juarez, L.M., Lockwood, G.S., et al. 2020. Achieving sustainable aquaculture: historical and current perspectives and future needs and challenges. Journal of the World Aquaculture Society, 51: 578633.

Castro-Rivera, R., Aguilar, B.G. \& Hernández, G.J.P. 2005. Conversión alimenticia en engordas puras y mixtas de popoyote (Dormitator latifrons Richardson) en estanques de cemento. AquaTIC, 23: 45-52.

Food and Agriculture Organization (FAO). 2018. The state of world fisheries and aquaculture 2018: meeting the sustainable development goals. FAO, Rome.

López-Huerta, J., Vega-Villasante, F., Viana, M.T., Carrillo-Farnés, O. \& Badillo-Zapata, D. 2018. First report of nutritional quality of the native fish Dormitator latifrons (Richardson, 1844) (Perciformes: Eleotridae). Latin American Journal of Aquatic Research, 46: 849-854.

Munguti, J.M., Kim, J.D. \& Ogello, E.O. 2014. An overview of Kenyan aquaculture: current status, challenges, and opportunities for future development. Fisheries and Aquatic Science, 17: 1-11.

Milstein, A. 1992. Ecological aspects of fish species interactions in polyculture ponds. Hydrobiologia, 231: 177-186.

Papoutsoglou, S.E., Miliou, H., Karakatsouli, N.P., Tzitzinakis, M. \& Chadio, S. 2001. Growth and physiological changes in scaled carp and blue tilapia under behavioral stress in mono and polyculture rearing using a recirculated water system. Aquaculture International, 9: 509-518.

Rahmatullah, R., Das, M. \& Rahmatullah, S.M. 2010. Suitable stocking density of tilapia in an aquaponic system. Bangladesh Journal of Fisheries Research, 14: 29-35.

Rodríguez-Montes de Oca, G.A. \& Dabrowski, K. 2015. Growth and body composition of midas (Amphilophus citrinellus) and Nile tilapia (Oreochromis niloticus) reared in duoculture. Revista Colombiana de Ciencias Pecuarias, 28: 255-264.

Rodríguez-Montes de Oca, G.A., Medina-Hernández, E., Velázquez-Sandoval, J., López-López, V.V., Román- 
Reyes, J.C., Dabrowski, K. \& Haws, M.C. 2012. Production of chame (Dormitator latifrons, Pisces: Eleotridae) larvae using GnRHa and LHRHa. Revista Colombiana de Ciencias Pecuarias, 25: 422-429.

Ronald, N., Gladys, B. \& Gasper, E. 2014. The effects of stocking density on the growth and survival of Nile tilapia (Oreochromis niloticus) fry at Son fish farm, Uganda. Journal of Aquaculture Research \& Development, 5: 1-7.

Tahoun, A.A., Suloma, A., Hammouda, Y., Abo-State, H. \& El-Haroun, E. 2013. The effect of stocking different ratios of Nile tilapia Oreochromis niloticus, striped mullet Mugil cephalus, and thinlip grey mullet Liza ramada in polyculture ponds on biomass yield, feed efficiency, and production economics. North American Journal of Aquaculture, 75: 548-555.

Vega-Villasante, F., Cueto-Cortés, L., Basto-Rosales, M.E.R., Badillo-Zapata, D., Chong-Carrillo, O., RuizGonzález, L.E., et al. 2017. Ocurrence of Argulus sp. in Dormitator latifrons culture: prevalence, mortality and treatment. Revista Bio Ciencias, 4: 1-14.

Received: 26 November 2020; Accepted: 19 January 2021
Violante-González, J., Rojas-Herrera, A. \& AguirreMacedo, L. 2008. Seasonal patterns in metazoan parasite community of the "fat sleeper" Dormitator latifrons (Pisces: Eleotridae) from Tres Palos Lagoon, Guerrero, Mexico. Revista de Biología Tropical, 56: 1419-1427.

Wang, M. \& Lu, M. 2016. Tilapia polyculture: a global review. Aquaculture Research, 47: 2363-2374.

Yáñez-Arancibia, A. \& Díaz-González, G. 1977. Trophicdynamic ecology of Dormitator latifrons (Richardson) in nine coastal lagoons on the Pacific coast of Mexico (Pisces: Eleotridae). Instituto de Ciencias del Mar y Limnología, 19: 140. 